\title{
Resources Concerning the History of Polish Jews in Castle Court Records of the 17Th and 18Th Centuries in the Central State Historical Archives in Kyiv and Lviv
}

\author{
Przemysław Zarubin \\ (iD) https://orcid.org/0000-0003-4845-0839 \\ (Jagiellonian University in Krakow, Poland) \\ e-mail: przemyslaw.zarubin@uj.edu.pl
}

Keywords: archival sources, Ukraine, Lviv, Kyiv, castle court, 17th century, 18th century

\begin{abstract}
The article presents types of sources which have thus far not been used, castle court books kept in the archives of the Ukrainian cities of Lviv and Kyiv. The author emphasizes the importance of these sources for research on the history and culture of Polish Jews in the 17th and 18th centuries. He also specifies the types of documents related to Jewish issues authenticated in these books (e.g. manifestations and lawsuits, declarations of the Radom Tribunal), as well as current source publications and internet databases containing selected documents from Ukrainian archives.
\end{abstract}

The Central State Historical Archive in Lviv (CDIAL) (known as the Bernadine Archive) and the Central State Historical Archive in Kyiv (CDIAUK) both have extensive collections of records of the so-called castle courts (sady grodzkie), also known as local Starost courts (sady starościńskie) for the nobility: from the Bełz and Ruthenian Voivodeships in the Lviv archive; and from the Luck, Podolia, Kyiv, and Bracław Voivodeships in the Kyiv archive. This is particularly important because - in the light of Jewish population counts taken in 1764-1765 for the purpose of poll tax assessment - these areas were highly populated by Jews. $44 \%$ of the Jewish population of the Polish-Lithuanian Commonwealth lived in the Red Ruthenia and Ukraine area. The largest Jewish populations lived in the Ruthenian (over 110,111), Volhyn (50,792), and Podolia Voivodeships $(38,384)$. The Jewish-to-Christian population ratio in these voivodeships was also the highest in the Crown (The Kingdom of Poland). The largest Jewish communities in the mid-18th century were those in Brody (approx. 7,000) and Lviv (approx. 6,000). ${ }^{1}$ From the second half of the 17th century to the first half of the 18th century, these areas were the centre of Jewish life with regards to economy (including the leasing of serfdombased farms on the estates of magnates (magnateria), activities in fairs and trade routes, and the leasing of inns and mills (arenda)), politics (participation in Jewish congresses and councils), and religion.

\footnotetext{
${ }^{1}$ Hundert 2007: 45-49.
} 
Ukrainian collections of castle court records from the former territories of Poland have been used in research on the history of Polish Jews in the pre-partition period selectively and to a limited degree. Much better explored in this respect is the collection of the Bernadine Archive in Lviv, because in the inter-war period these records, though mainly concerning Lviv and Przemyśl, were partly reviewed by Polish scholars of Jewish origin. On the other hand, the complicated history of the Kyiv archive rendered it inaccessible to Polish researchers for a long time. Only after Ukraine became an independent state in 1991 and closer collaboration with Ukrainian archivists and historians began, particularly through the digitalization project "Zapomniane pomniki cywilizacji europejskiej. Spuścizna aktowa I Rzeczypospolitej w archiwach państw powstatych po rozpadzie ZSRR. Ze szczególnym uwzględnieniem zespołów ksiag sądowych (do 1831 r.) w zasobach archiwalnych Ukrainy"2 "The Forgotten Monuments of European Civilisation. Legacy of Records of the First Republic of Poland in the State Archives Established after the Collapse of the USSR, with Particular Focus on "Gentry" Court Records (until 1831) in Ukrainian Archives"), did they become more widely known.

To date, only a few individual documents from castle court records (księgi grodzkie) have been published by Sergey Alexandrovich Bershadsky, ${ }^{3}$ Mathias Bersohn, ${ }^{4}$ and most importantly - by Majer Bałaban; ${ }^{5}$ some of them have been also included in the publication Arkhiv Iugo-Zapadnoi Rossii, featuring mainly documents from CDIAUK, that is from Kyiv and Żytomiersk (Zhytomyr) castle court records, ${ }^{6}$ and some documents from Lviv and Przemyśl castle court records, pertaining to a Jewish council (Sejm), have been published by Adam Kaźmierczyk and Jakub Goldberg. ${ }^{7}$ More extensive materials concerning Jews from Lviv and Przemyśl castle court records have been used by Dawid Wurm ${ }^{8}$ and Mojżesz Schorr, ${ }^{9}$ the authors of monographs on Jewish communities in Przemyśl and Brody, respectively. A separate category of records are the successively published "lauda," resolutions adopted by the Crown dietines (sejmiki koronne), ${ }^{10}$ included in castle court records, where the debating gentry often addressed Jewish issues (mainly related to taxes) or bans on the lease of customs duties or on keeping Christian servants. It should be noted that several Jewish documents from Przemyśl castle court records are available online in the form of scans on the website of Repozytorium Cyfrowe Poloników [Digital Repository Polonica] courtesy of CDIAUL. ${ }^{11}$ These are not the only Jewish materials from castle court records available on-line. One interesting concept is a database of approximately 2,000 documents concerning Jewish self-government institutions entitled "Żydowski samorząd ziemski w Koronie (XVII-XVIII wiek)"

2 Machynia 2013: 83-95; Nykiel 2013: 59-83; Kurtyka 2005: 93-114.

3 Bershadski 1882-1903.

4 Bersohn 1910; Bershadski 1880.

5 Bałaban 1906; Bałaban 1932: 41-65.

6 AJZR 1869; AJZR 1890.

7 Goldberg, Kaźmierczyk 2011. Followed by Kaźmierczyk, Zarubin 2019. Some documents were also published by I. Halperin and I. Bartal, see: Halperin 1945. Extended and supplemented edition by I. Bartal.

8 Wurm 1935.

9 Schorr 1903.

10 AGZ 1868-1931; Stolicki 2002.

11 Project: Digitalization of set 13 (Judicium Castr. Premisliense) from the Ukrainian Central Historical Archives in Lviv. Stage II (contract no. 876 /P-DUN/2015). The original titles in Latin make the search more difficult. 
("Jewish Territorial Self-Government in the Crown in the Seventeenth and Eighteenth Centuries"), presenting the functioning of territorial organisation of Jews in the Crown, available on the website of the Institute of Jewish Studies of the Jagiellonian University. It contains a selection of documents, commonly in the form of summary registers, originating mainly from castle court records of Lviv, Przemyśl, and Halicz (CDIAL) as well as of Łuck and Włodzimierz (CDIAUK). ${ }^{12}$ As interest in the pre-partition period is gradually decreasing, it is particularly important that documents concerning Jewish history and culture be made available in the form of summary registers. To date, only castle court records of the Kraków Voivodeship (the reign of King Jan III Sobieski) and of the Lublin Voivodeship (the reign of Sigismund III Vasa until Augustus II) have been published in a similar form, by A. Kaźmierczyk and H. Gmiterk, respectively. ${ }^{13}$

Often, in the absence of other sources, castle court records kept by castle court and office scribes were the only traces of a Jewish presence in a given area. Materials of Jewish provenance, namely community record books, the so-called "pinkas," private documents, and particularly writings of Jewish officials rabbis, ushers, syndics, and elders of the kahals, as well as documents produced as a result of the activities of Jewish congresses (Vaads) and councils got lost in the 18th-19th century or were destroyed, mainly during the Second World War. Hence, Jewish life and the reality of the time needs to be reconstructed on the basis of other sources, such as documents of state authorities (laws adopted by the sejm, mandates and rescripts of the king and his officials), local authorities (lauda (resolutions) of the dietines of local nobility (sejmik szlachecki)), church authorities (acts issued by bishops and judicial vicars), and of private individuals, mainly representatives of influential and wealthy magnate families.

The main kahals of the Crown were usually located in large Crown cities (e.g. Kraków, Lviv, Przemyśl) which - to a certain degree - determined and shaped the direction of historical research. Generally, researchers (except for the above-mentioned Majer Bałaban) use town council and town bench records (księgi wójtowsko-ławnicze) as well as municipal council records, but not castle court ones, as their main source of research on Jewish people, and - specifically - on their relations with the Christian world of the time. In city halls of large cities, record books of various magistrate divisions were divided into separate series and kept according to a pre-defined pattern. Separation of individual categories of matters considerably facilitates the research. In castle court offices this division was not so clear, and decree (judgement) record books (ksiegi dekretowe) were combined with report record books (księgi relacyjne) (e.g. in the Żytomierz (Zhytomyr) castle court records).

Even preserved old estate materials drawn up in offices of magnate families, presenting mutual Christian-Jewish relations in magnate estates, raise more interest among researchers than the continuously ignored castle court records. ${ }^{14}$ Preliminary research

\footnotetext{
${ }^{12}$ See http://www.ziemstwa.judaistyka.uj.edu.pl/katalog-ziemstw.

${ }_{13}$ Kaźmierczyk 1995; Kaźmierczyk 2009; Gmiterek 2001; Gmiterek 2003; Gmiterek 2006; Gmiterek 2014.

${ }_{14}$ Rosman 2005 (Czartoryski-Sieniawski collection in Czartoryski Library in Krakow); Teller 2016; Hundert 1992 (Opatowski Estate Archive in AGAD), Kaźmierczyk, Goldberg 2011 (i.a. Sanguszko Family Archive and Tarnowscy Family Archive so-called "Dzikowskie" in The National Archives in Krakow; CDIAUK, Tarło Family Archive, Fond 254, i.e. voivodes of Lublin and Sandomierz; CDIAL, Lanckoronscy Family of Rozdol Archive, Fond 181: Acts of Waclaw Rzewuski Podolia voivode).
} 
into castle court records, whether in Polish or Ukrainian state archives, poses considerable problems. They are usually superficial and are treated as complimentary to the preliminary research of city/town or estate records. The number and volume ${ }^{15}$ of castle court records means they require meticulous and time-consuming preliminary research. Unfortunately, the indexing of selected record book series, if any, is often insufficient and contains numerous errors, and therefore it does not accurately present the contests of acts recorded therein. Quite often, the title itself does not say anything about the content of a given document. Interesting documents relating to or concerning Jews or Jewish affairs, found particularly in proceeding documents (summons, decrees), such as disputes between magnates concerning runaway Jewish leaseholders of inns, relevant from the perspective of migration processes, hardly ever have accurate titles. Moreover, Jewish affairs were not of any particular importance to a plaintiff or a person making a complaint, which was reflected in the official writing filed with a castle court, based on specific legal writing templates.

Therefore, in order to obtain the desired results, it is recommended that all volumes of record books be conscientiously reviewed, with particular attention paid to report record books (księgi relacyjne) and small claim court records (ksiegi potoczne). ${ }^{16}$ Another serious obstacle for many researchers is the language barrier. Generally, from the beginning of the reign of Stanisław August Poniatowski, apart from Polish the other dominant language in castle court offices was Latin, while until the mid-17th century the castle court records of Podolia, Bracław, Volhyn, and Kyiv Voivodeships were kept in Russian, which poses a particular challenge to Polish researchers not familiar with palaeography of the Russian language. It should be noted that some castle court records containing interesting - from the perspective of Jewish history - information are preserved only in the form of hardly legible drafts or minutes, or even only summary registers of the cases (e.g. Krzemieniec (Kremenets) castle court records), while some other series of record books contain mainly inscriptions and decrees, which are less relevant in the context of Jewish studies.

An attempt could be made to conduct a subjective review of records pertaining to Jews found in the castle court records of both of these Ukrainian archives, and to assess their research value. CDIAL has the following series of castle court record books: Bełz (Fond 1), Busk (Fond 3), Halicz (Halych) (Fond 5), Lviv (Fond 9), Przemyśl (Fond 13), Sanok (Fond 15), Trembowla (Fond 17), Żydaczów (Zhydachiv) (Fond 7). The CDIAU archives hold the record books from Kyiv (Fond 2), Żytomierz (Zhytomyr) (Fond 11), Owrucz (Ovruch) (Fond 15), Luck (Lutsk) (Fond 25), Włodzimierz (VolodymyrVolynskyi) (Fond 28), and fragmentary collections of record books from Krzemieniec, Bracław, Kamieniec Podolski, and Winnica, which do not contain any valuable Jewish material related to the period concerned. The most valuable collection of castle court records kept in CDIAUK containing materials related to Jewish history are the castle court records from Włodzimierz, which is the westernmost larger town in the Volhyn

15 Putiwnik 2001: 61. E.g. the collection "Sąd grodzki lwoski" (Lviv Castle Court Collection), fond 9 in CDIAL for the period 1440-1786 comprises: 962 books, 101 indexed folders, 32 non-indexed folders, 602 indices. While "Sąd grodzki przemyski” (Przemyśl Castle Court) collection fond 13 for the period 1462-1784 comprises as many as 1099 books, 260 indexed folders, 32 non-indexed copies of files, and 1326 indices.

${ }^{16}$ In CDIAL's and CDIAUK's inventories marked as “czistovaja aktovaja kniga." 
Voivodeship and is situated near the most important Jewish centres in the Chełm-Bełz lands (the towns of Chelm and Bełz). The most valuable collection of castle court records kept in CDIAUK containing materials related to Jewish history are the castle court records from Włodzimierz - the westernmost larger town in the Volhyn Voivodeship, situated near the important Jewish centre in Chełm Land, or in the Bełz or Ruthenian Voivodeships. They contain documents concerning, inter alia, the communities in Włodzimierz, Łokacze, Kowel, and Krzemieniec. This collection - to a considerable extent very well-preserved - is exceptional among all the castle court record books kept by CDIAUK. It records documents concerning the whole community of Volhyn Jews. It is so also because local rabbis enjoying a special position in the Volhyn Land (ziemstwo wotyńskie), that of a trustee (general scribe) in charge of accurate assessment of Jewish poll tax (poglowne), resided in Włodzimierz, only $33 \mathrm{~km}$ from Łokacze. From being a general scribe one could be promoted to the office of Crown Jews' scribe and make a true career. In 1689, King Jan III Sobieski appointed Fiszel Lewkowicz (Fiszel ben Arie Lejb), a royal servitor, the general scribe of Crown Jews (known as the "wiernik" (trustee)), and allowed him to build a distillery and a malt house in Włodzimierz, releasing him from jurisdiction of any court, except for his own and the marshal's court, and from debts owed to the Włodzimierz community. ${ }^{17}$ The Włodzimierz castle court records tell a story of unsuccessful attempts of his son, Tewel Lewkowicz, to inherit these positions from his father, and of protests against irregularities in assessment of Jewish poll tax filed by kahals against his father Fiszel Tewlowicz, the local trustee (wiernik ziemski) and Rabbi of Łokacze, highlighting irregularities in assessing the Jewish poll tax to individual Jewish communities, or excessive tax assessment. ${ }^{18}$ These are examples of the very few similar documents evidencing a general tendency observed at that time among Jews, where persons holding rabbinic offices would take up senior royal positions (particularly that of a trustee), and where land elder and trustee positions were inherited.

Also worth mentioning among the most significant documents is a declaration of a Radom Tribunal on improving Jewish poll tax collection, dated $1747,{ }^{19}$ and a tax ordinance on the form of collection of Jewish poll tax in the Volhyn Land, issued in 1696 by the Grand Crown Treasurer (podskarbi wielki koronny) Hieronim Augustyn Lubomirski. ${ }^{20} \mathrm{~A}$ rare example of authentication in the castle court records of letters in Hebrew translated to Polish is an oblata (a document entry) dated 1751, included in the correspondence of the elders of the Volhyn Voivodeship and of the Łuck and Mielnik kahal with the Kowel kahal. ${ }^{21}$

The Włodzimierz castle court records also hold information on the conversion of the wife of the Rabbi of Włodzimierz, dated $1749-1751,{ }^{22}$ on the kidnapping of a peasant from a bishop's estate by Jews with the intention to sell him into military service, dated $1739,{ }^{23}$ and assurance by the elders from the Jewish organisation Chevra Kadisha in

17 Kaźmierczyk, Goldberg 2011: 97.

${ }_{18}$ CDIAUK, Fond 28, desc. 1, case 151: 203v-204v, 239r-240r, 943 rv; Fond 28, desc. 1, case 152: $395 \mathrm{rv}, 481 \mathrm{v}-482 \mathrm{v}$.

19 CDIAUK, Fond 28, desc. 1, case 166: 1322r-1323v.

${ }^{20}$ CDIAUK, Fond 28, desc. 1, case 141: 705v-707r.

${ }^{21}$ CDIAUK, Fond 28, desc. 1, case 170: 719r-720v.

22 Ibid.: 100v-101r, 940rv.

${ }^{23}$ CDIAUK, Fond 28, desc. 1, case 160: 91r-92r. 
Włodzimierz extended to a local parish church. ${ }^{24}$ A typical document which evidences the role of a bishop in establishing Jewish places of worship is the 1747 consent of Bishop Kobielski of Łuck issued to the Jews of Kowel to renovate their synagogue, cemetery and beth-hamidrash. ${ }^{25}$ Among documents issued to Jewish communities it is worth mentioning the confirmation of privileges granted to the Jews of Kowel in 1700 by King August II, acknowledging their rights, including the privilege granted by Queen Bona Sforza in $1547 .{ }^{26}$ The activities of tax authorities towards Jews are illustrated by, among others, oblata of extracts from Lviv hiberna tax books (hiberna - "winter bread" - a tax to cover expenses of accommodation of troops during wintertime), a declaration of the Lviv hiberna tax commission for Jewish fire victims from Maciejow, dated 1707, ${ }^{27}$ and hiberna tax assignations to individual cavalry units, such as that dated 1756 to Kurdwanowski, the Starost (governor) of Baranów. ${ }^{28}$

The 18th-century Łuck castle court records are poorly preserved. This is a major loss, as Łuck was one of the most important Jewish communities in the Volhyn area. Moreover, the Bishop of Łuck in 1739-1755 was Franciszek Kobielski, known for his initiatives to convert Jews. The most important 17 th-century documents include letters of the Grand Crown Treasurer, Hieronim Augustyn Lubomirski to Łuck district elders, concerning excessive tax assessment in Ostrożec community, dated 1695, as well as numerous poll tax assignations for the Jews of Luck and Kisielin. ${ }^{29}$ An interesting document illustrating the functioning of the castle court office (kancelaria grodzka) is a letter of the Crown Treasurer and Łuck starost Atanazy Miączyński, dated 1692, to the officials of the Łuck castle court office, forbidding them to take podwoda (obligation to make saddle horses available for the needs of the lord or his officials) from local Jews and Karaites for their own private use. ${ }^{30}$ Among the earlier documents worth mentioning is a universal issued by King Jan Kazimierz Vasa in 1656, on the tax issues applicable to the Crown Jews. One of the few 18th-century documents is a universal issued by the Grand Crown Hetman (commander-in-chief) Adam Mikołaj Sieniawski, dated 1716, concerning a poll tax, addressed to Volhyn Jews. ${ }^{31}$

Although almost all of the Kyiv Castle court records were calligraphed by Żytomiersk castle court clerks and were written in good Polish, they are not very rich in materials concerning Jewish matters. An important document, but from a later period, showing the number of Jews in the Kresy (borderlands) are lists of Jewish poll tax dues from the year 1765 drawn up in the Crown and Lithuania in order to set new Jewish poll tax rates after liquidation of Jewish autonomy by the Convocation Sejm (Sejm Konwokacyjny) in 1764. In the same way we can find the tax dues from Kyiv district, and individual kahals such as those of Kaniów, Rożów, Smiła, and Iwanków. ${ }^{32}$ A declaration of the Radom Treasury

${ }^{24}$ Ibid.: $863 \mathrm{r}-864 \mathrm{v}$.

${ }_{25}$ CDIAUK, Fond 28, desc. 1, case 166: 1140r-1141r.

26 CDIAUK, Fond 28, desc. 1, case 145: 828r-832v.

${ }^{27}$ CDIAUK, Fond 28, desc. 1, case 146: 90r-92v.

${ }_{28}$ CDIAUK, Fond 28, desc. 1, case 173: 476r-479r.

${ }^{29}$ CDIAUK, Fond 25, desc. 1, case 434: 710rv, op1/443: 16r-17v; Fond 25, desc. 1, case 450: 292v$293 \mathrm{v}$.

30 CDIAUK, Fond 25, desc. 1, case 434: 757r-758v.

31 CDIAUK, Fond 25, desc. 1, case 455: 1rv.

${ }^{32}$ CDIAUK, Fond 2, desc. 1, case 68: 62r-77r, 94v-97r. Cf. AJZR 1890. 
Tribunal dated 1718 , recorded as late as in 1747 , is particularly valuable, as it describes a dispute between the Crown Vaad (the Council of Four Lands) and the Lithuanian Vaad, concerning the control over Jews from small towns of Owrucz district, who paid a poll tax not to the Kyiv kahal, but to the Minsk one, which resulted in insufficient money to pay the hiberna tax for the Crown cavalry units. ${ }^{33}$ Irregularities in setting the poll tax rates are highlighted in a summons filed with Radom Treasury Tribunal, dated 1761, against the rabbis from Ostróg and Krzemieniec, who had committed numerous abuses and misappropriations of funds, having imposed excessive tax rates on some communities on the pretext of repayment of wyderkauf (a common name for the purchase of an annuity). ${ }^{34}$

Żytomiersk Castle court records mostly concern cases concerning Jewish leases, moral issues, and debts. As regards treasury matters, one example worth mentioning is a record (oblata) of the poll tax assignations of the Treasurer Jan Jerzy Przebendowski owed by Jews from Włodzimierz, based on the distribution by the elders of the Volhynian lands, dated $1726 .{ }^{35}$ In other collections of castle court records kept in the Kyiv Archives Jewish matters are relatively rare. The series of decree record books are particularly limited, unlike in Krakow castle courts, for example, where separate criminal books were kept, and minutes were taken of the hearings. The majority of the records pertain to civil law cases, such as intromission, inheritance/testamentary cases, cases concerning small amounts of money, and cases filed against runaway leaseholders who had not adequately performed their contractual obligations.

The CDIAL's collection of castle court records is much more extensive and also better explored, mainly by Polish and Ukrainian historians. The Lviv and Przemyśl castle court records contain the largest number of cases (volumes). The Lviv castle court records, as it should be expected of the capital of the Ruthenian Voivodeship and one of the major cities of the Crown, present a varied and rich spectrum of Jewish cases of the time. Naturally, the largest part of the preserved documents pertains to the functioning of both Jewish communities of Lviv, the urban and the suburban, their relations with the city, the local noblity and burghers (mieszczanie), and particularly to the extended loans and executed wyderkauf contracts. The universals of crown and hetman treasurers are particularly numerous, as the hiberna tax commission was operating in Lviv. In 1704, Jan Jerzy Przebendowski, the Grand Crown Treasurer, ordered the elders of the Crown Jews to reduce the tax imposed on Jews from the town of Sieniawa, which had suffered considerably during the war. ${ }^{36}$ In 1723, the same treasurer addressed the elders of the Ruthenian Voivodship in a matter of the Jewish council (sejmik żydowski) in Bóbrka, which was to decide on the Jewish poll tax. ${ }^{37}$ The attitude of Polish authorities towards the return to Judaism by people forced to conversion during the Chmielnicki Uprising and the war with Moscow is shown in the universal of King Jan Kazimierz, dated 1649, recorded in 1650, permitting baptised Jews who converted to the Orthodox faith to return

${ }^{33}$ CDIAUK, Fond 2, desc. 1, case 39: 284r-285r. Traces of the dispute can be also found in the Mlynowskie Archives of Chodkiewicz Family (Archiwum Młynowskie Chodkiewiczów) in the National Archives in Krakow, having in its collection individual vidimus copies from Owrucz castle court records.

${ }^{34}$ CDIAUK, Fond 2, desc. 1, case 57: 470-471.

35 CDIAUK, Fond 11, desc. 1, case 25: 194r-195r.

36 CDIAL, Fond 9, desc. 1, case 63: 265-266.

37 CDIAL, Fond 9, desc.1, case 64 [fragments]: 1634-1636. 
to the Jewish faith. ${ }^{38}$ A relatively large number of documents in Lviv castle court records was entered there upon orders by Ruthenian voivodes who accredited their documents not only in the voivode record books (ksieggi wojewodzińskie). For example, in 1752, the Ruthenian Voivode August Czartoryski summoned a Jewish congress of the lands (ziemstwa) of the Ruthenia Voivodeship in his town of Przemyślany and appointed Jan Mikołaj Cieszkowski, the pantler (stolnik) of Stężyca, to act as his commissioner, tasked with reviewing the expenditures and incomes of the lands in recent years. ${ }^{39}$ The king's letters and mandates addressed to the highest rank officials and magnates living in Kresy are also entered in the court records. For instance, in 1730, August II appealed to the Ruthenian Voivode Jan Stanisław Jabłonowski to help Lviv Jews who had problems with leaseholders from nearby villages and towns trying to break away from their authority. ${ }^{40}$ The most important documents concerning demographic and settlement matters are Jewish poll tax assignation lists for the Ruthenian and Bracław Voivodeships for 1764-1765, and the liquidation of the Ruthenian Land (ziemstwo ruskie) in $1766 .{ }^{41}$ It should be noted that, apart from settling the debts of Jews from the Bełz Voivodeship and Chełm Land, it is one of the two such preserved documents concerning Crown Jews showing the structure and extent of Jewish indebtedness in the whole Voivodeship, or rather its territorial organisation into lands, (ziemstwo) with autonomous Jewish government executives.

Although the Jews of the Przemyśl and Rzeszów communities became autonomous and formed separate tax areas, Przemyśl castle court records do not tell how and when it had happened. However, the documents contained in these records suggest that emancipation of individual communities, separation of less important faraway areas (partykularz) from their parent communities, and rivalry for influence among kahal elders were turbulent processes indicative of a crisis in Jewish autonomous government in the first half of the 18th century. A decree of the Przemyśl consistory is a very rare document. It shows church interference in disputes between communities, as it settles a dispute concerning affiliation of minor kahals (przykahalki) between the communities in Przemyśl and Turka. It was issued by Przemyśl judicial vicar (oficjat), the Bishop of Tanis, Przemyśl Suffragan Bishop Andrzej Pruski, in Przemyśl on 6 September 1755, resolving a dispute between the synagogues in Przemyśl and Turka concerning the affiliation of minor kahals, mentioning approximately 70 villages having Jewish residents. ${ }^{42}$ Conflicts between Jewish communities are also evidenced by documents of the 1730s and 1740s, such as lawsuits filed with the Radom Tribunal, as well as complaints and counter-complaints filed by the elders of the Leżajsk and Tarnogród communities ${ }^{43}$ and similar ones dated to the 1730s and 1740s showing conflicts between the communities in Chyrów and Dobromil. ${ }^{44}$ Due to the relatively small number of preserved records from Rzeszów, a private city of the Lubomirski family, interesting documents concerning Rzeszów Jews were recorded in the nearby Przemyśl castle court records. They include, among others, information on the disputes between the Rzeszów community and

\footnotetext{
38 CDIAL, Fond 9, desc. 1, case 400: 65-67. Cf. Kaźmierczyk 2015: 66-67.

39 CDIAL, Fond 9, desc. 1, case 565: 1229-1330.

40 Ibid.: 1227-1228.

${ }^{41}$ CDIAL, Fond 9, desc. 1, case 599: 10-57; Fond 9, desc. 1, case 959: 2637.

${ }^{42}$ CDIAL, Fond 13, desc. 1, case 596: 2774-2783.

${ }^{43}$ CDIAL, Fond 13, desc. 1, case 523: 268-269.

44 CDIAL, Fond 13, desc. 1, case 575: 590-593; Fond 13, desc. 1, case 554: 945-947.
} 
the communities in Ropczyce, Sędziszów, and Dębica between the 1730s and 1750s, and disagreements with the Jews of Tyczyn enjoying protectorate of the owners of these lands, the Branicki family. ${ }^{45}$

Apart from the Lviv and Przemyśl record books, particularly valuable information concerning Jewish populations can be found in the districts of the former Bełz Voivodeship. The gentry of this small Voivodeship and the local Jews authenticated their documents in as many as four castle courts: in Grabowiec and Horodło (the records from these districts are kept by the State Archives in Lublin) as well as in Bełz and Busk, now in Ukraine. The majority of the documents recorded in these districts pertain to main kahals from the Bełz Voivodeship, Chełm Land, and Zamość Entitled Estate (Ordynacja Zamojska), and particularly to Stojanów, Lubaczów, Chełm, Bełz, Czerwonogród (called Krystynopol), Busk, Sokal, and even Zamość. Among the traces of typical business and the financial activities of Jews, such as execution of contracts of lease of inns, income, or villages, assurance of financial liabilities, wyderkauf arrangements, or complaints concerning debts, there are some true archival gems to be found. Given the nature of castle court records, the traces of other Jewish activities, particularly cultural, are hard to find. One such document found in the Bełz castle court records is a privilege granted by King Jan III Sobieski in 1680 to Filip Lewie and Dawid Filip Lewie, allowing them to print the Talmud and other Jewish books in Żókiew, with the right to sell them throughout the territory of the Crown and Lithuania. ${ }^{46}$ It is also worth mentioning a privilege of Wiktoria Gintoft, the wife of the Terleszyn Starost, in 1723, allowing the merger of Jews from neighbouring communities of Narol and Lipsk, and authorising them to use the same synagogue and cemetery ${ }^{47}$ and other privileges granted to the community of Sokal, authenticated in castle court records of $1750 .{ }^{48}$ Certain documents reflect a rivalry within Chełm-Bełz land among the elders of the main kahals, such as a universal of Franciszek Salezy Potocki, the Starost of Bełz, on the equality of Chełm and Bełz land elders, recorded in Bełz castle court records in 1735..$^{49}$ In such cases, the Grand Crown Treasurer had to interfere as a party interested in the collection of poll tax, which is evidenced by the privilege of the Treasurer Karol Odrowąż Sedlnicki concerning the office of the general trustee (wiernik) of Bełz and Chełm lands, granted in 1751 in Konstantynów, and recorded in the Bełz castle court records..$^{50}$

Sanok castle court records contain a few documents concerning the Polish Jewish population, the majority of them being of a local nature (pertaining mainly to Jews from Sanok, Lesko, and Rymanów), including accusations against the Jews from Sanok area of having caused cattle disease in $1747,{ }^{51}$ or a universal from the same year by the al-

${ }^{45}$ CDIAL, Fond 13, desc. 1, case 538: 2297-2299; Fond 13, desc. 1, case 540: 1505-1506; Fond 13, desc.1, case 599: 106-108.

${ }^{46}$ CDIAL, Fond 1, desc. 1, case 322: 539-545. Along with approval dated 1731 by the Duke of Oława, the king's son Jakub Ludwik Sobieski. Cf. Gąsiorowski 2001: 122. Recorded in 1703 in Żółkiew town council and town bench records. The author gives an erroneous amount of the deposit to be forfeited in the case of a breach of the monopoly for printing books in the Ruthenian Voivodeship, as 2,000,000 Polish zlotys instead of 2,000 ducats.

47 CDIAL, Fond 1, desc. 1, case 309: 520-521.

${ }^{48}$ CDIAL, Fond 1, desc. 1, case 344: 950-957.

${ }^{49}$ CDIAL, Fond 1, desc. 1, case 324: 553-554.

${ }^{50}$ CDIAL, Fond 1, desc. 1, case 345: 1814-1815.

${ }^{51}$ CDIAL, Fond 15, desc. 1, case 238: 72-75, 704-705. 
ready mentioned Treasurer Sedlnicki addressed to the elders of Ruthenian lands concerning an excessive poll tax imposed on Jews from Lesko. ${ }^{52}$ The consent granted to the Sanok rabbinate for Mendel Lejzorowicz in 1720, issued by the Grand Marshal of the Crown (marszałek wielki koronny) Józef Wandalin Mniszech ${ }^{53}$ is an interesting albeit typical document which stands as evidence that taking up of the office of a rabbi in a given community was conditional upon the consent of the local magnate (nobleman) and lord. Another interesting case, from a cultural and social perspective, is a mysterious event of 1722 concerning a black cock dressed in traditional Jewish clothes buried at a crossroads in the village of Tyrawa Wołoska. ${ }^{54}$

The Halicz castle court records provide far less information on Jewish matters than those of Lviv and Bełz. Most of the records pertain to debts, wyderkauf arrangements, lease contracts and the Jewish populations of Halicz, Tyśmienica, and Stanisławów. There are also consents to the construction of synagogues, including consent given by archbishop Mikołaj Wyżycki in 1754 to the Jews of Stanisławów. ${ }^{55}$ Particularly valuable are the documents concerning Karaites (Halicz was an important Karaite community), especially their relations with the Jewish population, such as the privilege of Kyiv voivode and Halicz starost Józef Potocki granted to the Halicz Karaites in 1704, obliging the elders of the Ruthenian Voivodeship to protect the Halicz Karaites from being sued before the voivode court instead of the starost court. ${ }^{56}$ Among a number of similar royal universals preserved in various series of castle court record books, aimed at facilitating the collection of Jewish poll tax, there is a protective universal issued by king Jan Kazimierz for the Crown Jews in $1668 .{ }^{57}$ A register of expenditures and incomes of a Ruthenian land marshal dated 1722-1725, found in Halicz castle court records ${ }^{58}$ is worth special attention, as it shows treasury-related aspects of functioning of Jewish self-government.

The entries in the castle court records of Trembowla and Żydaczów concerning Jews are also of a local nature, and they refer mainly to the Jews of the Czortków, Kolomyja, and Trembowla communities (Trembowla castle court records) and of the Rozdol, Stryj (Stryi), and Żydaczów communities (Żydaczów castle court records). Among the most interesting documents are a universal of the Grand Crown Treasurer Jan Jerzy Przebendowski, forbidding Crown Jews to lease private customs, dated $1727,{ }^{59}$ recorded in Trembowla castle court records, and one concerning a settlement agreement between Trembowla magistrate with Trembowla Jews, dated $1726 .{ }^{60}$

To sum up, it should be noted that castle court records kept in both of these Ukrainian archives, although only partly preserved, provide extensive information about Jews. This is not surprising, because many Jews had settled down in the eastern borderlands area since the Middle Ages. Despite the damage caused by Cossack and Polish soldiers during the Chmielnicki Uprising in 1648-1657, the epidemics of the first half of the 18th

${ }^{52}$ CDIAL, Fond 15, desc. 1, case 238: 2342-2347.

${ }^{53}$ CDIAL, Fond 15, desc. 1, case 208: 1921-1922.

${ }_{54}$ CDIAL, Fond 15, desc. 1, case 215: 292-297.

${ }_{55}^{5}$ CDIAL, Fond 5, desc. 1, case 261: 1179-1182.

${ }^{56}$ CDIAL, Fond 5, desc. 1, case 246: 1361-1363.

${ }^{57}$ CDIAL, Fond 5, desc. 1, case 165: 1684-1687.

58 CDIAL, Fond 5, desc. 1, case 225: 1333-1340.

${ }^{59}$ CDIAL, Fond 17, desc. 1, case 172: 531-532.

${ }^{60}$ CDIAL, Fond 17, desc. 1, case 171: 1127-1132. 
century, robberies, and military requisitions of the Great Northern War of 1700-1721, the Jewish communities managed to rebuild their economic and demographic potential. This was possible due to the well-developed system of leaseholds, where Jews played a dominant role, and to their engagement in commodities and agriculture. The many Polish magnate families, including the Potockis, Czartoryskis, and Jabłonowskis, readily granted privileges to Jews, perceiving them as a force capable of revitalising these lands, which were severely damaged by the military conflicts. Subsequent rulers often acknowledged the privileges granted to Jewish communities, while church authorities granted consents to the building of synagogues. It should be noted, however, that castle court records contain judicial and administrative records showing a specific, somewhat false, aspect of reality reflecting the perspective of the nobility. Therefore, as an autonomous source, they do not present a complete picture of the Jewish population of the time. Yet, since treasury records, particularly those from the Royal Treasury Archives and Treasury Tribunal in Radom and those from major centres such as Sandomierz or Nowy Korczyn, were lost in the Second World War, it seems reasonable that the research on the history of Polish Jews should focus on more and more accessible Ukrainian archives, and castle courts records in particular. Materials concerning Jewish affairs kept in CDIAUL and CDIAUK should be of interest not only to researchers interested in the history of Jews but also military history and the Polish treasury system, as well as to linguists, historians of law, and anthropologists. It seems reasonable to continue to publish thematic summary registers of documents from castle court records, or at least to accelerate their digitalisation and make the results of the process available on the Internet and digital media. ${ }^{61}$

\section{ABBREVIATIONS}

AGAD - Central Archives of Historical Records in Warsaw

AJZR - Arkhiv Iugo-Zapadnoi Rossii

CDIAUK - Central State Historical Archive in Kyiv

CDIAL - Central State Historical Archives of Ukraine in Lviv

$\mathrm{Cf}-$ confer

$\mathrm{rv}-$ recto verso

\section{BIBLIOGRAPHY}

\section{Archival sources}

CDIAUK

Fond 2: desc. 1, case 39; desc. 1, case 57; desc. 1, case 68.

Fond 11: desc. 1, case 25 .

Fond 25: desc. 1, case 434; desc. 1, case 443; desc. 1, case 450; desc. 1, case 455 .

Fond 28: desc. 1, case 141; desc. 1 , case 145 ; desc. 1 , case 146 ; desc. 1 , case 151 ; desc. 1 , case 152 ; desc. 1 , case 160 ; desc. 1 , case 166 ; desc. 1 , case 170; desc. 1 , case 173.

${ }^{61}$ To read more about the publication of sources concerning history of Polish Jews see: Kaźmierczyk 2011: 81-86. 


\section{CDIAL}

Fond 1: desc. 1, case 309; desc. 1, case 322; desc. 1, case 324; desc. 1, case 344; desc. 1, case 345.

Fond 5: desc. 1, case 165; desc. 1, case 225; desc. 1, case 246; desc. 1, case 261 .

Fond 9: desc. 1, case 63; desc. 1, case 64 [fragments]; desc. 1, case 400; desc. 1, case 565; desc. 1, case 599; desc. 1, case 959 .

Fond 13: desc. 1, case 523; desc. 1, case 538; desc. 1, case 540; desc. 1, case 554; desc. 1, case 575; desc. 1, case 596; desc. 1 , case 599.

Fond 15: desc. 1, case 208; desc. 1, case 215; desc. 1, case 238.

Fond 17: desc. 1, case 171; desc. 1, case 172.

\section{Printed sources}

Akta grodzkie $i$ ziemskie $z$ czasów Rzeczypospolitej Polskiej z archiwum tak zwanego bernardyńskiego we Lwowie $w$ skutek fundacyi śp. Alexandra hr. Stadnickiego, (1868-1931), published by Galicyjski Wydział Krajowy, vol. 1-24. [AGZ], http://www.wbc.poznan.pl/dlibra/ publication? $\mathrm{id}=44646 \& \mathrm{tab}=3$.

Arkhiv Iugo-Zapadnoi Rossii, (1869), part V, vol. 1, Akty o gorodach 1432-1798, Kyiv. [AJZR]

Arkhiv Iugo-Zapadnoi Rossii, (1890), part V, vol. 2, Perepisy ewrejskago naselenija w jugo-zapadnom krai 1765-1791, Kyiv. [AJZR], https://books.google.pl (Archiv über das südwestliche Russland.)

Bersohn, M. (1910), Dyplomataryusz dotyczacy Żydów w dawnej Polsce, Warsaw, https://polona.pl/ item/dyplomataryusz-dotyczacy-zydow-w-dawnej-polsce-na-zrodlach-archiwalnych-osnuty1388-1782,MTU0ODkwODE/12/\#item.

Bershadski, S.A. (1880), Matieriały dla istorii Evreev w Iugo-Zapadnoj Rossii i Litwie, Eveieyskaya Bibliotieka, vol. 8.

Bershadski, S.A. (1882-1903), Russko-Evreyski Arkhiv, vol. 1-3, Petersburg.

Gąsiorowski, S. (2001), Chrześcijanie i Żydzi w Żótkwi w XVII i XVIII wieku, Kraków.

Gmiterek, H. (2001), Materiaty źródtowe do dziejów Żydów w księgach grodzkich lubelskich z doby panowania Augusta II Sasa (1697-1733), Lublin, http://biblioteka.teatrnn.pl/dlibra/dlibra/docm etadata $\mathrm{id}=8939 \&$ from $=\&$ dirids $=1 \&$ ver_id=\&lp=2\&QI=1242906F2B7BEFB61E0C0C27D4A 6E232-1

Gmiterek, H. (2003), Materiaty źródłowe do dziejów Żydów w księgach grodzkich lubelskich z doby panowania Michała Korybuta Wiśniowieckiego i Jana III Sobieskiego (1669-1697), Lublin.

Gmiterek, H. (2006), Materiały źródłowe do dziejów Żydów w księgach grodzkich lubelskich z doby panowania Władysława IV i Jana Kazimierza Wazów (1633-1669), Lublin.

Gmiterek, H. (2014), Materiały źródłowe do dziejów Żydów w księgach grodzkich lubelskich z doby panowania Zygmunta III Wazy (1587-1632), Lublin.

Goldberg, J., and Kaźmierczyk, A. (2011), Sejm Czterech Ziem. Źródła, Warszawa.

Halperin, I. (1945), Pinkas Waad Arba Aracot (Kronika czterech ziemstw, hebr.), Acta Congressus Generalis Judaeorum Regni Poloniae (1580-1764), Jerusalem (extended and supplemented edition: I. Bartal, Jerusalem 1989-1990).

Kaźmierczyk, A. (1995), Materiały źródłowe do dziejów Żydów w księgach grodzkich dawnego województwa krakowskiego z lat 1674-1696, vol. 1, Kraków.

Kaźmierczyk, A. (2009), Materiaty źródtowe do dziejów Żydów w księgach grodzkich dawnego województwa krakowskiego z lat 1674-1696, vol. 2, Kraków.

Kaźmierczyk, A., and P. Zarubin (2019), Żydowski samorząd ziemski w Koronie (XVII-XVIII wiek). Źródła, Kraków.

Stolicki, J. (2002), Akta sejmiku podolskiego in hostico 1672-1698, Kraków.

\section{Online sources}

Project: Jewish self-government in the Crown (17th-18th century) http://www.ziemstwa.judaistyka. uj.edu.pl/katalog-ziemstw. 
Repozytorium Cyfrowe Poloników http://www.repcyfr.pl/dlibra (password: urząd grodzki or księgi grodzkie przemyskie).

\section{Primary literature}

Bałaban, M. (1906), Żydzi lwowscy na przełomie XVI-go i XVII-go wieku, Lviv, http://rcin.org.pl/dlibra/doccontent?id=15090.

Bałaban, M. (1932), Z zagadnień ustrojowych żydostwa polskiego. Lwów a ziemstwo ruskobracławskie w XVIII, Studia Lwowskie: 41-65, http://www.wbc.poznan.pl/dlibra/ doccontent?id=82204\& from $=$ FBC.

Hundert, G.D. (1992), The Jews in a Private Polish Town. The Case of Opatów in the Eighteenth Century, Baltimore.

Hundert, G.D. (2007), Żydzi w Rzeczypospolitej Obojga Narodów w XVIII wieku. Genealogia nowoczesności, Warszawa.

Kaźmierczyk, A. (2015), Rodziłem się Żydem... Konwersje Żydów w Rzeczypospolitej XVII-XVIII wieku, Kraków.

Kaźmierczyk, A. (2011), Kilka uwag o wydawaniu tekstów do dziejów Żydów, in: Teoria i praktyka edycji nowożytnych źródet w Polsce (XVI-XVIII w.), ed. A. Perłakowski, Kraków: 81-86.

Kurtyka, J. (2005), Zapomniane pomniki cywilizacji europejskiej. Zespoły ksiąg sądowych szlacheckich i miejskich z czasów I Rzeczypospolitej (XV-XVIII w.) w Kijowie, Rocznik Krakowski 71: 93-114.

Machynia, M. (2013), Zapomniane pomniki cywilizacji europejskiej. Zespoły ksiąg sądowych "szlacheckich" z czasów I Rzeczypospolitej (XVI-XVIII w.) w Centralnym Państwowym Archiwum Historycznym Ukrainy w Kijowie. Stan badań i zamierzenia, in: Stan badań nad wielokulturowym dziedzictwem dawnej Rzeczypospolitej, ed. W. Walczak, K. Łopatecki, Białystok: 83-94.

Nykiel, B. (2013), Kolekcja grodzkich i ziemskich ksiąg sądowych w Centralnym Państwowym Archiwum Historycznym Ukrainy w Kijowie w świetle projektu "Zapomniane pomniki cywilizacji europejskiej," in: Stan badań nad wielokulturowym dziedzictwem dawnej Rzeczypospolitej, ed. W. Walczak, K. Łopatecki, Białystok: 59-83.

Putiwnik (2001), Centralnyj dzierżawnyj istoricznyj archiw Ukrainy m. Lwiw. Putiwnik [Central State Historical Archives of Ukraine in Lviv. A Guide], researched by: O. Gniewiszewa, U. Edlinska, D. Pelc, G. Swarnik, I. Swarnik, and N. Franko, Lviv-Kyiv.

Rosman, M. (2005), Żydzi pańscy. Stosunki magnacko-żydowskie w Rzeczypospolitej XVIII wieku, Warszawa.

Schorr, M. (1903), Żydzi w Przemyślu do końca XVIII wieku, Lviv, http://www.pbc.rzeszow.pl/dlibra/ doccontent?id $=4828$.

Teller, A. (2016), Money, Power, and Influence in Eighteenth-Century Lithuania. The Jews on the Radziwitl Estates, Stanford.

Wurm, D. (1935), Z dziejów żydostwa brodzkiego za czasów dawnej Rzeczypospoliej (do r. 1772), Brody, http://rcin.org.pl/Content/10357/WA248_21620_F-22-682_wurm-z-dziejow-o.pdf. 
